\title{
Transatlantica
}

Revue d'études américaines. American Studies Journal

\section{Probing the Unorthodox and Reappraising Nonconformity: Recent Historiographical Perspectives on Early America and the Antebellum Period}

\section{Auréliane Narvaez}

\section{OpenEdition}

\section{Journals}

Electronic version

URL: https://journals.openedition.org/transatlantica/16730

DOI: 10.4000/transatlantica. 16730

ISSN: 1765-2766

\section{Publisher}

Association française d'Etudes Américaines (AFEA)

\section{Electronic reference}

Auréliane Narvaez, "Probing the Unorthodox and Reappraising Nonconformity: Recent

Historiographical Perspectives on Early America and the Antebellum Period", Transatlantica [Online], 1 । 2021, Online since 29 June 2021, connection on 06 February 2023. URL: http://

journals.openedition.org/transatlantica/16730 ; DOI: https://doi.org/10.4000/transatlantica. 16730

This text was automatically generated on 6 February 2023 


\title{
Probing the Unorthodox and Reappraising Nonconformity: Recent Historiographical Perspectives on Early America and the Antebellum Period
}

\author{
Auréliane Narvaez
}

1 Over the past several decades, critical developments in the study of early America and the antebellum era have reshaped the ways we think about this period of American history. ${ }^{1}$ Scholars have examined the interaction between early American national and individual identities; they have expanded the geographical as well as chronological limits of early America; they have shown how the dynamics of the Atlantic world were embedded in the very patterns of early American society, territory, and representations; and they have revealed how race, gender, and class operated in a shifting social and cultural context of emerging economic and political apparatuses. These interlocking perspectives on the period have provided opportunities not just to rethink seemingly fixed and stable categories and concepts but also to question national paradigms, conventional assumptions, and tales of exceptionalism. The possibility for new scholarly investigation and new interpretive frameworks has come along with the development of an interdisciplinary scholarship drawing on microhistory, social and intellectual history, cultural and literary studies, and visual and material culture studies, which are now all part of the early Americanist's toolkit and help us penetrate the complex fabric in which early American history is woven.

Without trying to provide a comprehensive overview of the many evolutions at work in the field of early American studies, my purpose in this brief essay is to review some recent trends that have refashioned our understanding of the period. In a series of compelling books representing a range of genres, including visual culture, social history, religious studies, and individual or collective biography, early American 
scholars have delved into what could be called the "unorthodox." The very etymology of the term invites us to consider what fails to fit into the admitted "doxa" which, in ancient Greek ( $\delta$ '́ $\xi \alpha)$, referred to the repository of common and often deceptive beliefs, perceptions, and assumptions. Taking the unorthodox seriously helps to focus our attention on the multifarious instances that complicate standard historical paradigms and resist conventional vistas. Reflecting on the historical expressions and embodiments of the unorthodox also forces us to face a form of discomfort and acknowledge the pervasive presence of the unheimlich at times of complex and often conflicting interactions, profound changes, and sometimes perplexing dynamics of modernity.

3 Interrogating conventional master narratives is not just about writing history from the margins; it is also a matter of bringing the margins to the center of our historical consideration and giving manifestations of the unorthodox, nonconformity, or deviance a positive value. In other words, probing the unorthodox is not restricted to showing how individuals, groups, ideas, or systems can depart from prevailing norms; it also illuminates how elastic and unstable the concepts of democracy, religion, family, race, gender, and nation were in early America and the antebellum period.

4 The current state of the historiography also invites us to reconsider the binary opposition between capacious works of macroscopic history that encompass a vast array of broadscale dynamics and microhistorical studies that consider singular units on smaller scales, generally to underscore the contradictions of larger normative structures and patterns. Though sometimes accused of fragmenting the field, microhistory has nonetheless proven highly suited to the analysis of the complex and often interlaced dynamics of race, gender, and capitalism in early America and the antebellum period. Conversely, larger studies have been useful to our understanding of early America as they have unveiled the transatlantic and transcontinental identities of a geographic area inextricably tied up to a vast network of interconnected streams and dynamics.

5 Drawing from these two historiographical approaches, recent scholarship has endeavored to reconcile the synoptic ambition of historical synthesis and the attention to peculiar or specific research topics that challenge historical paradigms. As evidenced by the works of Peter John Brownlee, Christopher Grasso, Sarah M.S. Pearsall, Jeremy Zallen, and others, the current historiography connects small and large scales by their overarching outlook on seemingly odd, disregarded, and unorthodox phenomena. This historiographical approach focuses on the dialectical interplay between progress and oppression, innovation and resistance to change, liberalism and bigotry, norms and margins, and it does so across a wide spectrum of specific occurrences and in a way that destabilizes our understanding of racial, religious, social, democratic, technological, and cultural dynamics. In an effort to articulate both broad and minute historical analysis and interpretations, the inquiry into the unorthodox allows historians to reflect on the paradoxical underpinnings of the early American and antebellum periods in ambitious works of substantial scope.

\section{Unorthodox Lives, Individual and Collective}

6 For the past forty years now, historical biographies have moved beyond the hagiographic celebration of eminent people's lives to consider how lesser-known 
individuals and groups made sense of their own experience. For all the recent attention paid to the biographical approach, however, a number of unorthodox trajectories have been overlooked. Exploring the field of individual and collective biographies from an unconventional vantage point has allowed early Americanists to uncover experiences that complicate traditional assumptions as they stand at the intersection of power struggles, social, racial, and gendered claims, paradigm shifts, and intellectual controversies.

7 In that respect, several publications have either adopted an unorthodox perspective on key figures of the early American period or turned their attention to unconventional individuals who challenged the norm-or perhaps what we assumed to be the norm.

Stephanie E. Jones-Rogers examines the much-surveyed history of slavery through an unorthodox lens, namely that of female enslavers, in her book They Were Her Property: White Women as Slave Owners in the American South (2019). Challenging the traditional assumptions and representations of women as passive (though complicit) observers standing on the fringes of the slaveholding system, Jones-Rogers shows how white women were largely involved in upholding the social, legal, and economic structures that supported the "peculiar institution," and in doing so she undermines several conventional premises. First, she undercuts the idea that women were excluded from economic transactions, business dealings, and more generally the history of capitalism in America. The book also questions the general perception of women as driving forces of social reform movements based on benevolence and morality for which they would be predestined given their supposedly higher susceptibility to emotions and empathy. Finally, the trajectories of female enslavers radically contradict the presumption that female empowerment is necessarily progressive, when in fact it could also prosper on human oppression and exploitation. Christine Walker revealed comparable dynamics at play in the colonies of the Anglo-Atlantic world in her study Jamaica Ladies: Female Slaveholders and the Creation of Britain's Atlantic Empire (2020). Questioning conventional assumptions through collective biographies was also the project of Kellie Carter Jackson in Force and Freedom: Black Abolitionists and the Politics of Violence (2019). By uncovering how black abolitionists resorted to violence both as a rhetorical instrument and as a practical strategy in order to fight slavery, Jackson destabilizes the common perception of abolitionism as primarily carried out by white activists advocating change through peaceful "moral suasion" in the Garrisonian tradition.

These unconventional narratives of seemingly unorthodox lives are central to our understanding of the dynamics of marginalization, exclusion, and coercion, as Kristin O'Brassill-Kulfan demonstrates in her book Vagrants and Vagabonds: Poverty and Mobility in the Early American Republic, which investigates the history of deviance and its policing through the lives of individuals who experienced indigence. More broadly, O'BrassillKulfan underscores how poverty encompassed a wide range of racial, ethnic, gendered, and professional identities. She unveils how these travelling poor, vagrants, and vagabonds subverted the legal norms that made illicit mobility a crime while navigating the currents of early nineteenth-century capitalism that encouraged the idea of a fluid, readily disposable, and adaptable workforce. By reclaiming the lives of these wandering unorthodox individuals, the book also stresses the ambiguities of early American capitalism, which profited from a form of labor mobility that was socially and legally criminalized. 


\section{Unorthodox Objects and Bodies}

10 Charting unorthodox territories also means encountering unorthodox bodies and unearthing unorthodox objects. The question of how the unorthodox materializes and acquires physicality through reified, commodified, or bodily forms is thus at the core of a number of studies that expose how vision worked as a medium through which the unorthodox could take shape.

11 In The Commerce of Vision: Optical Culture and Perception in Antebellum America (2018), Peter John Brownlee identifies the early nineteenth century as a pivotal period characterized by the development of new visual forms that refashioned how Americans perceived and interpreted the world around them. Technological breakthroughs such as the daguerreotype, the fat face letterform in typography, chromolithography, and the development of ophthalmic knowledge, encouraged what Brownlee calls a "market revolution in vision." These developments opened new avenues for labor productivity and cultural development but also created marginalized objects and bodies-those failing to adapt to this commodification of sight, who found themselves alienated because they could no longer read and make sense of their environment. The evolution of sight, no longer conceived as an objective and stable physical feature but reappraised as a skill worth nurturing in order to adapt to modernity, turns out to be double-edged insofar as enhanced visual technologies and cultural forms were not always synonymous with progress and could generate exclusion as well.

Recent publications also illuminate how vision, race, and gender could intersect in nineteenth-century America. The unreliability of racial categorizations is examined by Sharon Block in Colonial Complexions: Race and Bodies in Eighteenth-Century America (2018), which investigates the instrumentalization of physical appearance in the forging of racial ideologies. Drawing from thousands of advertisements for fugitive servants and slaves in colonial newspapers, Block reveals how biological features were translated into racial and social prejudices justifying a coercive labor system, but most importantly how racism was constructed by making variations from certain norms the very basis of a racialized interpretation of society.

13 In Girl in Black and White: The Story of Mary Mildred Williams and the Abolition Movement (2019), Jessie Morgan-Owens also analyzes how powerful the constructed categories of race and gender were in the antebellum period and how the new medium of photography could capture unorthodox objects and bodies as a way of subverting these fabricated norms. Morgan-Owens recounts how a seven-year-old girl whose light skin color made her pass as white was objectified as the abolition movement's (literal) poster child when abolitionists started circulating her photograph as an illustration of the cruelty of slavery as well as the absurdity of racial classification.

Photography did not thus necessarily disregard unorthodox subjects and bodies as the medium could in fact use them to convey political ideas and shift cultural paradigms. As such, it also contributed to the development of unorthodox visual forms such as spirit photography, as Justin T. Clark shows in City of Second Sight: Nineteenth-Century Boston and the Making of American Visual Culture (2018). Though living in an environment filled with images and objects, antebellum urban Americans developed a fascination for the invisible, which focalized the interest of those wishing to go beyond orthodox perceptions of a stable and objective reality standing in plain sight. Playing on the dialectical opposition between presence and absence and the ontological paradox of 
death being materialized and objectified, the dissemination of unorthodox objects such as spirit drawings or unconventional spirit photographs that captured the immaterial presence of the dead challenged the idea of a fixed and stable world.

The usage and instrumentalization of light-as a symbol of modernity and innovationis addressed in an unorthodox fashion by Jeremy Zallen in American Lucifers: The Dark History of Artificial Light, 1750-1865 (2019). Zallen departs from the orthodox perception of artificial light as a carrier of progress to show how the development of this simultaneously visible and invisible, material and immaterial force relied on practices that entailed environmental damage, animal and human abuse, social violence, and racial oppression through forced and perilous labor. This study of light as a commodity reveals the unorthodox trajectory of a resource that was central to the capitalist economy, and which had more to do with exploitation than with progressive enlightenment.

\section{Unorthodox Belief Systems and Practices}

Unorthodox belief systems also occupy center stage in a number of recent publications exploring unconventional social, religious, and cultural practices.

In Polygamy: An Early American History (2019), Sarah M.S. Pearsall confronts the traditional perception of plural union as a peculiar custom exercised by marginal and radical groups often characterized by a lesser degree of progress and urbanity. Monogamy, Pearsall argues, was not the absolute norm everywhere in North America and polygamy was more common than is traditionally assumed. Hence, the study denormalizes monogamy and challenges our representation of marginality by relocating the seemingly unorthodox at the center of the narrative and revealing that more than a few communities practiced polygamy for a variety of economic, social, sexual, or diplomatic reasons.

18 In a similar attempt at destabilizing conventional narratives, Christopher Grasso investigates belief systems commonly conceived as "marginal," "heterodox," and on the fringes of American religious history in his book Skepticism and American Faith: From the Revolution to the Civil War (2018). Religious skepticism has been obscured by decades of historiography that focused primarily on Protestantism as the main provider of religious beliefs, cultural codes, social standards, and civic and secular structures in early America. In this master narrative, skepticism has generally been described as a marginal intellectual position embraced by only a few educated men. Undermining this historical interpretation, Grasso transcends binary oppositions to reveal a more complex spiritual environment in antebellum America where the dominant position was not either belief or disbelief but the unrelenting oscillation between faith and doubt. This reappraisal of skepticism complicates the common depiction of the early nineteenth century as a period mainly characterized by a high degree of religiosity, and it illuminates the many ways in which Americans questioned orthodox religious doctrines and practices.

Bringing to light unorthodox belief systems and practices is also what Emily Ogden set out to do in Credulity: A Cultural History of US Mesmerism (2018). In this study of American mesmerism-which embraced a plurality of expressions including clairvoyance, therapeutic treatments, spirit travels, and spirit communications-Ogden examines the dark and ambivalent aspects of mesmeric techniques against the expectation that such 
practices would reenchant the world and inject some degree of magic in modern times. The book demonstrates that this admittedly unorthodox, unconventional belief system was also conceived as a new opportunity for manipulating people and serving modern ends such as factory supervision, productive labor, or forms of education that reinforced conventional economic, social, and cultural systems. The ambiguity of mesmerism as a place of enchantment but also as a tool for reinforcing systems of oppression thus unsettles the traditional binary opposition between enchantment and rationality, magic and modernity, wonder and secularity, and shows how the seemingly unorthodox could also be crafted so as to strengthen normative apparatuses. Unorthodox systems may be then as much the products of the modernity in which they emerge as the unlikely accessories of conventional social, economic, and cultural patterns and frameworks.

The scholarly interest in the unorthodox opens up novel and rich perspectives by decentering our conceptions of early American power structures, social interactions, and cultural values and practices. In so doing, it reveals the permeability and fluidity of the social, sexual, economic, and cultural patterns and identities in early America. By reassessing the manifold varieties of the unorthodox and by paying increased attention to the multifaceted presence of unconventional or heterodox lives, objects, bodies, thoughts, beliefs, and practices, recent scholarship illuminates the complexities of the early American and antebellum periods and demonstrates that the so-called margins may be the very places where the complexities, paradoxes, and intricacies of modernity unfold.

\section{BIBLIOGRAPHY}

BLOCK, Sharon. Colonial Complexions: Race and Bodies in Eighteenth-Century America. Philadelphia: University of Pennsylvania Press, 2018.

BROWNLEE, Peter John. The Commerce of Vision: Optical Culture and Perception in Antebellum America. Philadelphia: University of Pennsylvania Press, 2018.

CLARK, Justin T. City of Second Sight: Nineteenth-Century Boston and the Making of American Visual Culture. Chapel Hill: University of North Carolina Press, 2018.

GRASSO, Christopher. Skepticism and American Faith: From the Revolution to the Civil War. New York: Oxford University Press, 2018.

JACKSON, Kellie Carter. Force and Freedom: Black Abolitionists and the Politics of Violence. Philadelphia: University of Pennsylvania Press, 2019.

JONES-ROGERS, Stephanie E. They Were Her Property: White Women as Slave Owners in the American South. New Haven, CT: Yale University Press, 2019.

MORGAN-OWENS, Jessie. Girl in Black and White: The Story of Mary Mildred Williams and the Abolition Movement. New York: W. W. Norton, 2019. 
O'BRASSILL-KULFAN, Kristin. Vagrants and Vagabonds: Poverty and Mobility in the Early American Republic. New York: New York University Press, 2019.

OGDEN, Emily. Credulity: A Cultural History of US Mesmerism. Chicago: University of Chicago Press, 2018.

PEARSALL, Sarah M.S. Polygamy: An Early American History. New Haven, CT: Yale University Press, 2019.

WALKER, Christine. Jamaica Ladies: Female Slaveholders and the Creation of Britain's Atlantic Empire. Chapel Hill: University of North Carolina Press, 2020.

ZALLEN, Jeremy. American Lucifers: The Dark History of Artificial Light, 1750-1865. Chapel Hill: University of North Carolina Press, 2019.

\section{NOTES}

1. The author wishes to thank Will Slauter for his useful comments on this essay.

\section{AUTHOR}

\section{AURÉLIANE NARVAEZ}

Université Paris 1 Panthéon-Sorbonne 